\title{
Early Brain Injury Following Aneurysmal Subarachnoid Hemorrhage: Emphasis on Cellular Apoptosis
}

\author{
Anerrizmal Subaraknoid Kanama Sonrası Erken Beyin Hasar: \\ Hücresel Apopitoz Üzerine Tartı̧̧ma
}

\author{
Simge YUKSEL ${ }^{1}$, Yusuf Berk TOSUN ${ }^{1}$, Julian CAHILL ${ }^{2}$, Ihsan SOLAROGLU ${ }^{3}$ \\ ${ }^{1}$ Koc University, Faculty of Medicine, Neuroscience Research Lab., Sariyer, Istanbul, Turkey \\ ${ }^{2}$ University Hospitals Coventry and Warwickshire, Department of Neurosurgery, Coventry, United Kingdom \\ ${ }^{3}$ Koç University, Faculty of Medicine, Department of Neurosurgery, Sariyer, Istanbul, Turkey
}

Correspondence address: Ihsan SOLAROGLU / E-mail: isolaroglu@ku.edu.tr

\begin{abstract}
Subarachnoid hemorrhage ( $\mathrm{SAH}$ ) due to intracranial aneurysm rupture is a complex clinical disease with high mortality and morbidity. Recent studies suggest that early brain injury (EBI) rather than vasospasm might be responsible for morbidity and mortality within 24-72 hours after $\mathrm{SAH}$. The rise in intracranial pressure following SAH causes a significant drop in cerebral perfusion pressure that leads to global cerebral ischemia and initiates the acute injury cascade. Various molecular mechanisms have been shown to involve in the pathophysiology of EBI including cellular apoptosis. In this review, we summarize apoptotic molecular mechanisms involved in the etiology of EBI and its potential as a target for future therapeutic intervention.
\end{abstract}

KEYWORDS: Apoptosis, Early brain injury, p53, Stroke, Subarachnoid hemorrhage

öz

Intrakraniyal anevrizma rüptürüne bağlı gelişen subaraknoid kanama (SAK), yüksek mortalite ve morbidite ile seyreden kompleks bir hastalıktır. Yakın zamanda yapılan çalışmalar SAK sonrası 24-72. saatler içinde gelişen morbidite ve mortaliteden vazospasmdan ziyade, erken beyin hasarının sorunlu olduğunu ileri sürmüştür. SAK sonrasında gelişen intrakraniyal basınç artışı, serebral perfüzyon basıncında ciddi düşüşe neden olup global serebral iskemi ile sonuçlanır ve akut hasar kaskadını başlatır. Hücresel apopitoz dahil pek çok moleküler mekanizmanın erken beyin hasarının (EBH) patofizyolojisinde rol oynadığı gösterilmiştir. Bu derlemede; EBH etiyolojisinde rol alan apopitotik mekanizmalar ve bunların gelecekte potansiyel tedavi hedefi olarak önemleri özetlenmiştir.

ANAHTAR SÖZCÜKLER: Apopitoz, Erken beyin hasarı, p53, İnme, Subaraknoid kanama

\section{INTRODUCTION}

Each year approximately 10 out of 100,000 people experience a subarachnoid hemorrhage (SAH) due to intracranial aneurysm rupture $(26,28)$. Despite the recent developments in microsurgical and endovascular surgical techniques, the prognosis for patients who suffer a SAH remains unsatisfactory. $\mathrm{SAH}$ is a complex clinical disease that is often associated with many interrelated complications such as cerebral edema, obstructive hydrocephalus, diffuse/focal cerebral ischemia or infarction (35).

A common complication of SAH is vasospasm, which is still a leading cause of morbidity and mortality in patients with ruptured aneurysms that may occur 3-14 days following a $\mathrm{SAH}$. Angiographic evidence of vasospasm is seen in up to $70 \%$ of patients, and 20 to $30 \%$ of patient's manifest neurological deficits $(14,24)$. Vasospasm has been the focus of the majority of experimental and clinical research efforts during the past number of decades. Several types of treatment strategies such as circulatory volume expansion, statins, and magnesium sulfate and calcium antagonists have been studied in clinical trials to prevent or reverse vasospasm $(12,34,36,43)$. Based on the current evidence, only oral nimodipine is recommended as a standard treatment in patients with aneurysmal SAH (34). However, the reversal of vasospasm does not appear to improve outcome alone.

Delayed ischemic neurological deficits (DIND) due to vasospasm are rare within 3 days of SAH. Hence, the major causes of death within 72 hours following a SAH are the effects of the initial hemorrhage and aneurysmal rebleeding (4). A recently described concept early brain injury (EBI) looks at overall brain injury after $\mathrm{SAH}$ (5-7). Growing evidences have suggested that $\mathrm{EBI}$, which occurs during the $24-72 \mathrm{~h}$ following aneurysm rupture, largely contributes to unfavorable outcome (33). In this review, we summarize the current knowledge on 
the $\mathrm{EBI}$ and the apoptotic molecular mechanisms involved in the etiology of EBI.

\section{Early Brain Injury}

$\mathrm{EBI}$ is a term used to explain the pathophysiology that occurs within the brain after a SAH within the first 72 hours of the ictus. To date, both theoretically and clinically, this area has been neglected in favor of vasospasm, which typically occurs after the initial 72 hours. In addition, EBI challenges the already tenuous link between vasospasm and DIND. Although unproven, it can be suggested that EBI is a precursor for both DIND and vasospasm, which occur in parallel with each other and do not have a cause and effect relationship.

$\mathrm{EBI}$ is believed to arise from the significant pathophysiological mechanisms, which occur in the brain at the moment of a SAH.
The initial blood load causes an increase in the intracranial pressure (ICP), which has been demonstrated in both human and animal models. The quantity of the initial blood load drives the degree of the ICP rise. As the pressure rises the cerebral perfusion pressure (CPP) falls. The mechanism behind this relationship is imprisely understood, although it is believed to be related to the Monroe-Kelly hypothesis, furthermore both vasoparalysis and cerebrospinal fluid obstruction have also been implicated. The rise in the ICP and subsequent fall in the CPP result in a significant drop in the cerebral blood flow, which can in experimental studies drop to zero. While this is a transitory fall, the consequences are significant in both long and short term (Figure 1). These physiological derangements result in blood brain barrier dysfunction, inflammation, and oxidative cascades that lead to neuronal cell death (2) (Figure 2).

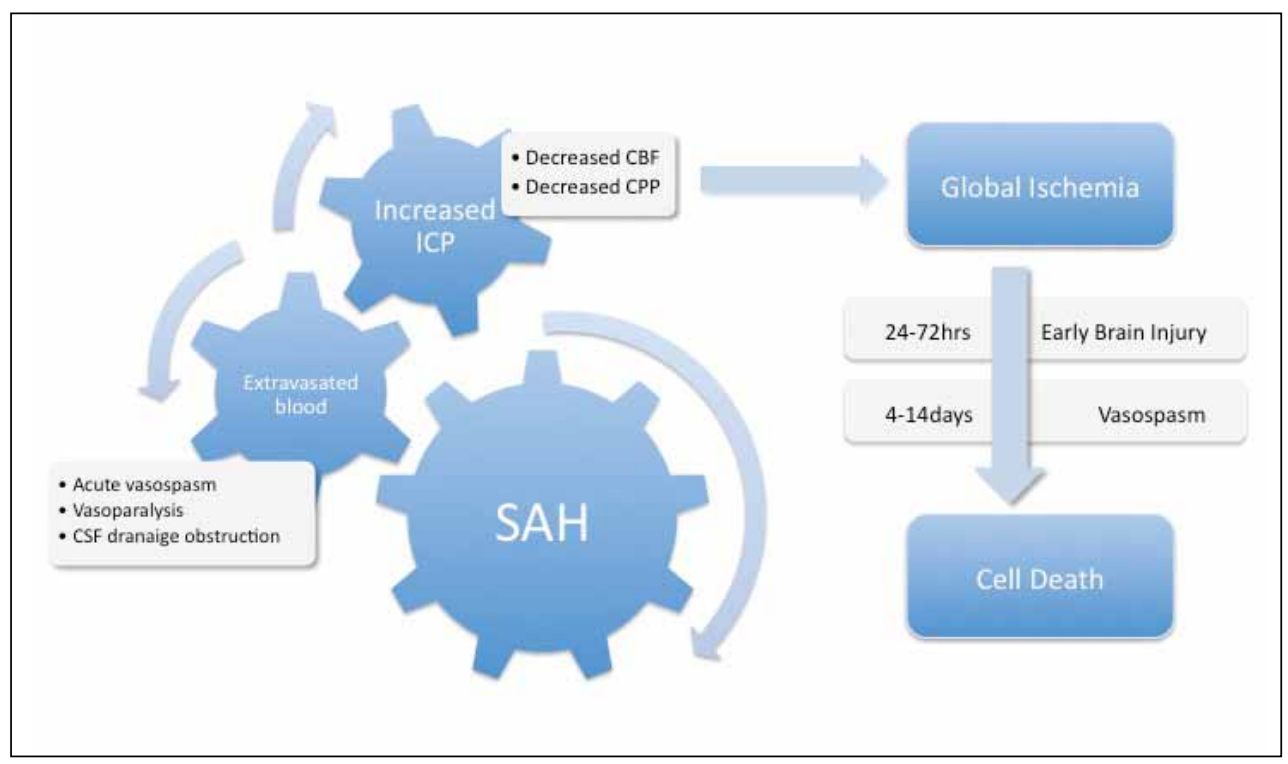

Figure 1: The figure shows overall scheme from $\mathrm{SAH}$ to global cerebral ischemia. Following $\mathrm{SAH}, \mathrm{ICP}$ rises and CPP drops significantly those results in decreased CBF. Global cerebral ischemia triggers EBI and consecutive vasospasm leading to neuronal cell death following SAH. CBF, cerebral blood flow; CPP, cerebral perfusion pressure; CSF, cerebral spinal fluid; $\boldsymbol{E} \boldsymbol{B} \boldsymbol{I}$, early brain injury; ICP, intracranial pressure; $\mathbf{S A} \boldsymbol{H}$, subarachnoid hemorrhage.

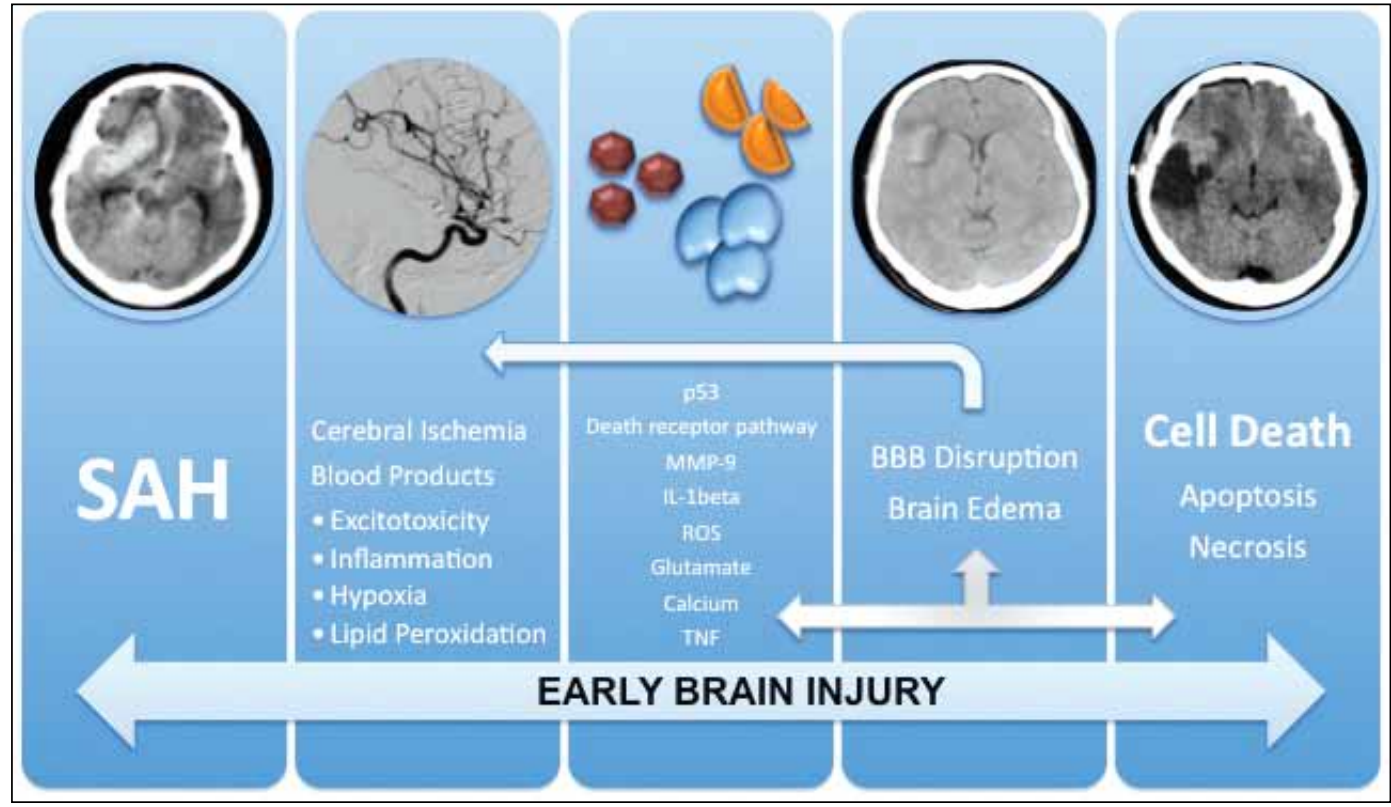

Figure 2: A recently described concept early brain injury looks at overall brain injury after $\mathrm{SAH}$. The figure shows mechanisms and molecular pathways involved in EBI. $E B I$, early brain injury; SAH, subarachnoid hemorrhage. 
These events result in a global ischemic injury, which varies in severity. Clearly in the most severe form the degree of ischemia is prolonged and results in death. This has been seen in post mortem studies where necrosis can be demonstrated throughout the brain. This occurs in about $30 \%$ of patients. In the remainder the degree of ischemia is not as severe and both apoptosis and to a lesser degree necrosis is evident. In grade one patients following a $\mathrm{SAH}$, the degree of injury is more subtle and is believed to be limited to apoptosis in more sensitive areas of the brain, for example the hippocampus. This has been demonstrated in both animal models and in patients post mortem $(30,31,44,46,47)$.

\section{Apoptosis in EBI}

Apoptosis is not a new concept, yet the complex and intricately interwoven pathways are still being elucidated. In addition, it appears that different pathways are important depending on the initial insult. For example, it has been shown that the caspase dependent cascade may be particularly important in relation to ischemia while the caspase independent cascade relates more to neurotoxin induced apoptosis (11). There are a number of pathways that are believed to be important in relation to $\mathrm{SAH}$; these include the death receptor pathway, p53, the caspase dependent and independent pathways and the mitochondrial pathway $(6,8,23)$.

$\mathrm{SAH}$ has been referred to as an external stress event which through a mechanism that is not fully understood (27) can initiate cellular apoptosis $(23,25)$. Apoptotic cell death may be seen in both cortical, subcortical or hippocampal neurons and endothelium following $\mathrm{SAH}$. It can be initiated through a variety of mechanisms including global ischemia due to increased ICP, microcirculatory disturbance, and subarachnoid blood toxicity (23). However, intracellular signaling pathways that are involved in mediating the apoptosis have not been fully investigated. Matrix metalloproteinase-9 (MMP-9), a member of endopeptidase family, can mediate apoptosis through cleaving main components of the extracellular matrix. The activity of MMP-9 and its substrate, laminin, are significantly altered in hippocampus following $\mathrm{SAH}$ in rats (21). Mitogen-activated protein kinases including extracellular signal-regulated kinase, c-Jun $\mathrm{N}$-terminal kinase (JNK), and p38 were reported to induce apoptosis in the brain and cerebral artery after SAH. It has been also shown that there is a link between JNK, MMP-9 and caspase-3 activation following $\mathrm{SAH}$. JNK not only induces a variety of proapoptotic proteins, such as c-Jun, p53, bim, and bax, but also inhibits anti-apoptotic proteins including $\mathrm{BCl}-2$ and $\mathrm{BCl}-\mathrm{xl}$ (40). However, activation of phosphoinositide 3-kinase / Akt (protein kinase B) pathway exerts anti-apoptotic properties by decreasing activation of proapoptotic caspases $(15,17,22)$.

It is believed that the death receptors within the cell membrane may be responsible for apoptotic cascade following $\mathrm{SAH}$. There are a number of receptors that have been examined including Fas, TNFR1 and DR3-5 that may be responsible for the translation of the signal across the cell membrane and the activation of the TNFR family. In particular, TNF-a and Fas have been shown to upregulate after a SAH $(44,45)$. These death receptors have been shown to be capable of activating the caspase cascades through a number of mechanisms (16). One of the most important mechanisms is the ability of the death receptors to stabilize p53 in the cytosol. Additional experimental studies examining the effects of pancaspase inhibitors have shown a favorable outcome with regard to $\mathrm{SAH}$, suggesting that p53 may work through either the caspase dependent or mitochondrial pathway in SAH induced apoptosis $(31,45)$.

P53 has been shown to be an orchestrating protein in the apoptotic pathways following a SAH (5-7). P53 is stabilized in the cytosol, which occurs through phosphorylation and occurs in response to any significant stress event including SAH (18). Once this occurs p53 activates the mitochondrial apoptotic pathway through the $\mathrm{Bcl}-2$ family of proteins, which are divided into both pro and anti-apoptotic members (19). Therefore, the Bcl-2 family can either stimulate or inhibit cytochrome $\mathrm{C}$ release from mitochondria depending on the dominant signal, i.e. pro or anti-apoptotic dominance (32). It is important to realize that apoptosis is not an all or none mechanism (38). P53 acting independently of the $\mathrm{Bcl}-2$ family can also initiate the caspase cascades through its action on procaspase 8 , which is cleaved to form caspase 8 which in turn cleaves Bid to form truncated Bid (tBid). tBid then permits the release of cytochrome $C$ from mitochondria which is further regulated by $\mathrm{BCl}-2$ and $\mathrm{BCl}-\mathrm{x}_{\mathrm{L}}$ (37). Once released, Cytochrome $C$ combines with Apaf- 1 to form the apoptosome, which in turn recruits and cleaves procaspase 9 , thereby activating the caspase cascade (29).

As mentioned, the apoptotic cascades can involve the intrinsic or mitochondrial pathway and the extrinsic pathway. The subsequent cascade, which the cell embarks upon, appears to be regulated, at least in part, by the availability of ATP. The mitochondrial pathway is energy dependent and occurs for example in the penumbra (3), where energy is still available. In ATP depleted areas, the extrinsic pathway, i.e. caspase 8, which is capable of self-cleavage, with direct activation of caspase 3, occurs. Hippocampal cells are far more prone to injury compared to other areas due to their sensitivity to ischemia as a result of high ATP requirements (31). Caspase 8 was also shown to decrease in experimental models of $\mathrm{SAH}$ induced apoptosis after the prevention of p53 stabilization in the cytosol, suggesting that the caspase dependent and mitochondrial release of cytochrome $\mathrm{C}$ are important in $\mathrm{SAH}$ (5-7). The importance of the apoptotic cascades has been shown to be significant not only within the brain parenchyma but also within the cerebral vasculature. It has been shown that apoptosis occurs in the endothelial cells of vessels, the prevention of which can attenuate the degree of vasospasm (45). Apoptosis has been identified in a patient who died from a SAH (46).

Experimental models of stroke and SAH have shown that the inhibition of caspases can offer some protection, however apoptosis still occurs $(31,42,45)$. Therefore, it seems clear 
that another caspase independent cascade may be involved. Apoptosis inducing factor (AIF) has been shown to be released from the mitochondria and translocate to the nucleus in response to various death signals $(9,10)$. P53 has been shown to trigger the release of AIF in the absence of Apaf- 1 resulting in a caspase independent apoptotic cascade (9). Interestingly in a similar way to cytochrome C, AIF appears to be under the control of the $\mathrm{Bcl}-2$ family and in fact the release of both AIF and cytochrome $\mathrm{C}$ are inhibited if $\mathrm{Bcl}-2$ members are blocked, suggesting that the $\mathrm{BCl}-2$ family may be solely responsible for the caspase dependent and independent cascades (9, 41). The $\mathrm{Bcl}-2$ family is also responsible for the inhibition of second mitochondria derived activator of caspase/direct IAP binding protein with low pl (Smac/Diablo) $(13,39)$, yet another mitochondrial protein similar to cytochrome $C$, which depresses procaspase-9 through the inhibition of inhibitor of apoptosis protein-1. This makes the $\mathrm{Bcl}-2$ family a powerful target for future therapeutic intervention.

\section{CONCLUSION}

Much progress has been made toward understanding the mechanisms of $\mathrm{EBI}$ following $\mathrm{SAH}$. As evidenced by the number of publications, apoptosis plays a significant role in $\mathrm{EBI}$, thereby could be a therapeutic target after SAH. However, much more work will be required to fully characterize the molecular signaling pathways regulating apoptosis in EBI.

\section{REFERENCES}

1. Adrain C, Creagh EM, Martin SJ: Apoptosis-associated release of Smac/DIABLO from mitochondria requires active caspases and is blocked by Bcl-2. EMBO J 20:6627-6636, 2001

2. Ayer R, Zhang J: Connecting the early brain injury of aneurysmal subarachnoid hemorrhage to clinical practice. Turk Neurosurg 20:159-166, 2010

3. Benchoua A, Guegan C, Couriaud C, Hosseini H, Sampaio $\mathrm{N}$, Morin $\mathrm{D}$, Onténiente $\mathrm{B}$ : Specific caspase pathways are activated in the two stages of cerebral infarction. J Neurosci 21:7127-7134, 2001

4. Broderick JP, Brott TG, Duldner JE, Tomsick T, Leach A: Initial and recurrent bleeding are the major causes of death following subarachnoid hemorrhage. Stroke 25:1342-1347, 1994

5. Cahill J, Calvert JW, Solaroglu I, Zhang JH: Vasospasm and p53-induced apoptosis in an experimental model of subarachnoid hemorrhage. Stroke 37:1868-1874, 2006

6. Cahill J, Calvert JW, Zhang JH: Mechanisms of early brain injury after subarachnoid hemorrhage. J Cereb Blood Flow Metab 26:1341-1353, 2006

7. Cahill J, Zhang JH: Subarachnoid hemorrhage: Is it time for a new direction? Stroke 40:S86-87, 2009

8. Cheng G, Wei L, Zhi-Dan S, Shi-Guang Z, Xiang-Zhen L: Atorvastatin ameliorates cerebral vasospasm and early brain injury after subarachnoid hemorrhage and inhibits caspasedependent apoptosis pathway. BMC Neurosci 10:7, 2009
9. Cregan SP, Fortin A, MacLaurin JG, Callaghan SM, Cecconi F, Yu SW, Dawson TM, Dawson VL, Park DS, Kroemer G, Slack RS: Apoptosis-inducing factor is involved in the regulation of caspase-independent neuronal cell death. J Cell Biol 158:507-517, 2002

10. Daugas E, Susin SA, Zamzami N, Ferri KF, Irinopoulou T, Larochette N, Prévost MC, Leber B, Andrews D, Penninger J, Kroemer G: Mitochondrio-nuclear translocation of AIF in apoptosis and necrosis. FASEB J 14:729-739, 2000

11. Dawson VL, Dawson TM: Deadly conversations: Nuclearmitochondrial cross-talk. J Bioenerg Biomembr 36:287-294, 2004

12. Dorhout Mees SM, Rinkel GJ, Feigin VL, Algra A, van den Bergh WM, Vermeulen M, van Gijn J: Calcium antagonists for aneurysmal subarachnoid hemorrhage. Stroke 39: 514-515, 2008

13. Du C, Fang M, Li Y, Li L, Wang X: Smac, a mitochondrial protein that promotes cytochrome c-dependent caspase activation by eliminating IAP inhibition. Cell 102:33-42, 2000

14. Dumont AS, Dumont RJ, Chow MM, Lin CL, Calisaneller T, Ley KF, Kassell NF, Lee KS: Cerebral vasospasm after subarachnoid hemorrhage: Putative role of inflammation. Neurosurgery 53:123-133, 2003

15. Duris K, Manaenko A, Suzuki H, Rolland WB, Krafft PR, Zhang $\mathrm{JH}$ : a7 Nicotinic acetylcholine receptor agonist PNU-282987 attenuates early brain injury in a perforation model of subarachnoid hemorrhage in rats. Stroke 42:3530-3536, 2011

16. Earnshaw WC, Martins LM, Kaufmann SH: Mammalian caspases: Structure, activation, substrates, and functions during apoptosis. Annu Rev Biochem 68:383-424, 1999

17. Endo H, Nito C, Kamada H, Yu F, Chan PH: Akt/GSK3beta survival signaling is involved in acute brain injury after subarachnoid hemorrhage in rats. Stroke 37:2140-2146, 2006

18. Giaccia AJ, Kastan MB: The complexity of p53 modulation: Emerging patterns from divergent signals. Genes Dev 12:2973-2983, 1998

19. Gross A, McDonnell JM, Korsmeyer SJ: BCL-2 family members and the mitochondria in apoptosis. Genes Dev 13:1899-1911, 1999

20. Guo Z, Sun X, He Z, Jiang $Y$, Zhang X, Zhang JH: Matrix metalloproteinase- 9 potentiates early brain injury after subarachnoid hemorrhage. Neurol Res 32:715-720, 2010

21. Guo ZD, Sun XC, Zhang JH: Mechanisms of early brain injury after SAH: Matrix metalloproteinase 9. Acta Neurochir Suppl 110:63-65, 2011

22. Hasegawa Y, Suzuki H, Altay O, Zhang JH: Preservation of tropomyosin-related kinase $B$ (TrkB) signaling by sodium orthovanadate attenuates early brain injury after subarachnoid hemorrhage in rats. Stroke 42:477-483, 2011

23. Hasegawa Y, Suzuki H, Sozen T, Altay O, Zhang JH: Apoptotic mechanisms for neuronal cells in early brain injury after subarachnoid hemorrhage. Acta Neurochir Suppl 110:43-48, 2011 
24. Kassell NF, Sasaki T, Colohan AR, Nazar G: Cerebral vasospasm following aneurysmal subarachnoid hemorrhage. Stroke 16:562-572, 1985

25. Kidd VJ: Proteolytic activities that mediate apoptosis. Annu Rev Physiol 60:533-573, 1998

26. Linn FH, Rinkel GJ, Algra A, van Gijn J: Incidence of subarachnoid hemorrhage. Role of region, year, and rate of computed tomography: A meta-analysis. Stroke 27: 625-629, 1996

27. Matz PG, Fujimura M, Chan PH: Subarachnoid hemolysate produces DNA fragmentation in a pattern similar to apoptosis in mouse brain. Brain Res 858:312-319, 2000

28. McCormickWF, Nofzinger JD: Saccular intracranial aneurysms: An autopsy study. J Neurosurg 22:155-159, 1965

29. Nijhawan D, Honarpour N, Wang X: Apoptosis in neural development and disease. Annu Rev Neurosci 23:73-87, 2000

30. Ostrowski RP, Colohan AR, Zhang JH: Mechanisms of hyperbaric oxygen-induced neuroprotection in a rat model of subarachnoid hemorrhage. J Cereb Blood Flow Metab 25:554-571, 2005

31. Park S, Yamaguchi M, Zhou C, Calvert JW, Tang J, Zhang JH: Neurovascular protection reduces early brain injury after subarachnoid hemorrhage. Stroke 35:2412-2417, 2004

32. Philchenkov A: Caspases: Potential targets for regulating cell death. J Cell Mol Med 8:432-444, 2004

33. Pluta RM, Hansen-Schwartz J, Dreier J, Vajkoczy P, Macdonald RL, Nishizawa S, Kasuya H, Wellman G, Keller E, Zauner A, Dorsch N, Clark J, Ono S, Kiris T, Leroux P, Zhang JH: Cerebral vasospasm following subarachnoid hemorrhage: Time for a new world of thought. Neurol Res 31:151-158, 2009

34. Rinkel GJ, Feigin VL, Algra A, van Gijn J: Circulatory volume expansion therapy for aneurysmal subarachnoid haemorrhage. Cochrane Database Syst Rev 18:CD000483, 2004

35. Solaroglu I, Kaptanoglu E, Okutan O, Beskonakli E, Taskin Y: Outcome of surgical management of 347 intracranial aneurysms in 305 cases. J Turkish Cerebrovascular Diseases 9:57-61, 2003

36. Trimble JL, Kockler DR: Statin treatment of cerebral vasospasm after aneurysmal subarachnoid hemorrhage. Ann Pharmacother 41:2019-2023, 2007
37. van Loo G, Saelens X, van Gurp M, MacFarlane M, Martin SJ, Vandenabeele $P$ : The role of mitochondrial factors in apoptosis: A Russian roulette with more than one bullet. Cell Death Differ 9:1031-1042, 2002

38. Vaux DL, Strasser A: The molecular biology of apoptosis. Proc Natl Acad Sci USA 93:2239-2244, 1996

39. Verhagen AM, Ekert PG, Pakusch M, Silke J, Connolly LM, Reid GE, Moritz RL, Simpson RJ, Vaux DL: Identification of DIABLO, a mammalian protein that promotes apoptosis by binding to and antagonizing IAP proteins. Cell 102:43-53, 2000

40. Yatsushige $H$, Ostrowski RP, Tsubokawa T, Colohan A, Zhang $\mathrm{JH}$ : Role of c-Jun N-terminal kinase in early brain injury after subarachnoid hemorrhage. J Neurosci Res 85:1436-1448, 2007

41. Xiang $H$, Hochman DW, Saya H, Fujiwara T, Schwartzkroin PA, Morrison RS: Evidence for p53-mediated modulation of neuronal viability. J Neurosci 16:6753-6765, 1996

42. Zhan RZ, Wu C, Fujihara $H$, Taga K, Qi S, Naito M, Shimoji $\mathrm{K}$ : Both caspase-dependent and caspase-independent pathways may be involved in hippocampal CA1 neuronal death because of loss of cytochrome c From mitochondria in a rat forebrain ischemia model. J Cereb Blood Flow Metab 21:529-540, 2001

43. Zhao XD, Zhou YT, Zhang X, Zhuang Z, Shi JX: A meta analysis of treating subarachnoid hemorrhage with magnesium sulfate. J Clin Neurosci 16:1394-1397, 2009

44. Zhou C, Yamaguchi M, Colohan AR, Zhang JH: Role of p53 and apoptosis in cerebral vasospasm after experimental subarachnoid hemorrhage. J Cereb Blood Flow Metab 25:572-582, 2005

45. Zhou C, Yamaguchi M, Kusaka G, Schonholz C, Nanda A, Zhang JH: Caspase inhibitors prevent endothelial apoptosis and cerebral vasospasm in dog model of experimental subarachnoid hemorrhage. J Cereb Blood Flow Metab 24:419-431, 2004

46. Zubkov AY, Ogihara K, Bernanke DH, Parent AD, Zhang J: Apoptosis of endothelial cells in vessels affected by cerebral vasospasm. Surg Neurol 53:260-266, 2000

47. Zubkov AY, Tibbs RE, Clower B, Ogihara K, Aoki K, Zhang $\mathrm{JH}$ : Apoptosis in basilar endothelial cells in a canine double hemorrhage model. Acta Neurochir Suppl 77:29-31, 2001 